\title{
TWO PATHS: THE PORT AND WORK OPTIONS IN THE SOUTH OF BAHIA BETWEEN 1872 AND 1940
}

(D) Flávio Gonçalves dos Santos ${ }^{1 ; 2}$

\section{ABSTRACT}

This article discusses how the Port of Ilhéus changed the social composition of the city, introducing new occupation types and areas of work. It seeks to disseminate some results of the project "Pontal Bay - Ilhéus: the city, the port and the Atlantic", financed by Bahia Research Foundation - FAPESB between 2012 and 2014,being currently funded by the National Council for Scientific and Technological Development - CNPq and by the Proyecto HAR2015-64044R - Global South. Puertos y desarrollo económico y social en el Atlántico meridional (1850-2010). The project was approved by the Ministry of Economy and Competitiveness of the Government of Spain - of the project "Estudo comparativo de sistemas portuários: Bahia-Brasil e Ilhas Canárias-Espanha - 1960/1990", financed by Universidade Estadual de Santa Cruz.

\section{KEYWORDS}

History-city-port-work.

1 Universidade Estadual de Santa Cruz. Ilhéus - Bahia - Brasil.

2 Flávio Gonçalves dos Santos teaches at UESC and holds a PhD in History from Universidade Federal Fluminense (UFF). E-mail: fgsantos@uesc.br. 


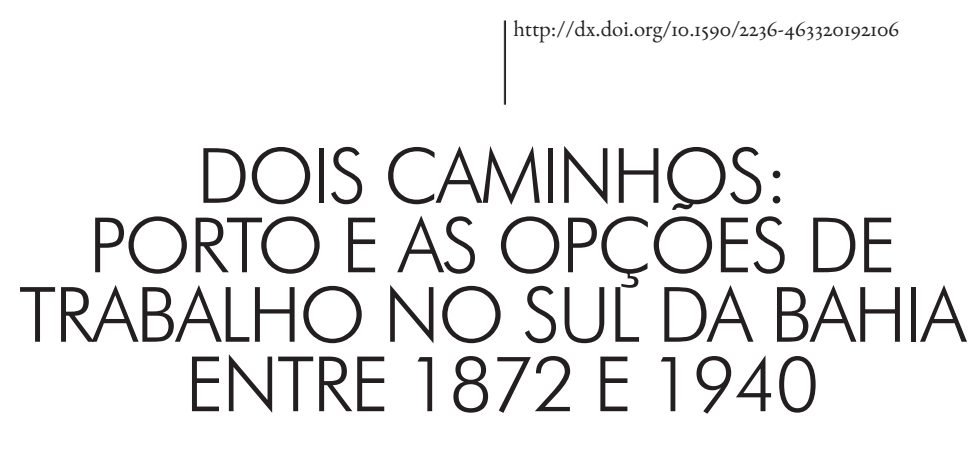

(D) Flávio Gonçalves dos Santos

\section{RESUMO}

Discute-se em que medida o Porto de Ilhéus alterou a composição social de sua cidade ao introduzir novos tipos de ocupações e ramos de trabalho. A partir dessa abordagem, o presente artigo apresenta alguns dos resultados dos projetos "Baía do Pontal - Ilhéus: a cidade, o porto e o Atlântico", inicialmente financiado pela Fundação de Amparo à Pesquisa do Estado da Bahia (Fafesb), entre o período de 2012 a 2014. Atualmente financiado pelo Conselho Nacional de Desenvolvimento Científico e Tecnológico (CNPq) e pelo Proyecto HAR2015-64044R - Global South. Igualmente, o estudo contempla pesquisas desenvolvidas nos seguintes projetos: Puertos y desarrollo económico y social en el Atlántico meridional (1850-2010), aprovado pelo Ministério de Economia e Competitividade do Governo da Espanha; e "Estudo comparativo de sistemas portuários: Bahia-Brasil e Ilhas Canárias-Espanha - 1960/1990", financiado pela Universidade Estadual de Santa Cruz (Uesc).

\section{PaLAVRAS-CHAVE}

História - cidade - porto - economia. 


\section{Introduction}

7 he State of Bahia was responsible for nearly $90 \%$ of the production and export of Brazilian cacao at the end of the $19^{\text {th }}$ century and throughout the $20^{\text {th }}$, which means that the southern region of Bahia contributed with almost all of this percentage. The volume of income introduced resulted that the City of Ilhéus, an urban conglomerate that only marginally participated in the state's economy, in just under fifty years became a dynamic regional center, with authority to interfere in the direction of Bahia's policies and to act with relevance in national politics.

Located between Latitude $14^{\circ} 47^{\prime} 20^{\prime} \mathrm{S}$, Longitude $39^{\circ} \mathrm{O} 2^{\prime} 56^{\prime} \mathrm{W}$, about $450 \mathrm{~km}$ from Salvador, the Capital of Bahia, Ilhéus is a coastal city, where the Rivers Santana, Cachoeira and Itaconoeira meet, and whose encounter with the sea results in the formation of the fluvial bay of Pontal. This space was used since the beginning of colonization and until the first quarter of XX century as a sheltered zone and natural port, when a succession of interventions endowed the city with an organized port. ${ }^{3}$

Ilhéus stood out from the other regions of the state that had an anchorage, used in great extent by the navigation of cabotage, for having initiated and carried out a process for the organization of a port, having, although in small amount, exported its products directly. However, the export of cocoa can never dispense the Port of Salvador and, concretely, there were few conditions to expand the infrastructure of

3 It should be noted that all references to the organized port, made in this text, within the chronological framework of the article should be understood as follows: "ports equipped with modern installations of port pier, breakwaters and other works of the same type, dredging and other services necessary to traffic of vessels, carried out by concession under the terms of Law no. 1746 , of October 13,1869, or by contract or administration, under the terms of decrees No. 4,859 of June 8, 1903 and 6,368, of February 14, 1907, these installments and their services will be in charge of the Ministry of Transport and Public Works, which will establish the respective 'Oporto Inspection' or equivalent in accordance with the provisions of this Regulation”. Brazil, Decree No. 15,693 ofSeptember 22, 1922. 
the Port of Pontal Bay, given the delays and difficulties of Companhia Industrial de Ilhéus in honoring the commitments signed in the concession contract. ${ }^{4}$

That said, the objective of this article is to identify how the Port of Ilhéus introduced new types of occupations and branches of work in a sensible manner as to interfere in the social composition of the city, not hindering the limits of its performance.

The methodological option adopted was to carry out a demographic analysis, based on census data from 1872, 1920 and 1940. With use of the demographic census, it was possible to verify that the interpretive work was based on approximations. Statistical data - not always built on the same methodological basis or choosing the same categories for counting - do not express reality in itself, but constitute a mosaic that allows the perception of trends or realities in the temporal cut (either conjunctural or of long duration) that is being investigated. It does not represent a faithful portrayal of society, but considering the amount of people it represents, it can provide the historian a broader perspective of the object of study.

Literature and photography were also used as sources of information on the context under investigation. Situated as between the historical-fictional witness of literature (which from logical inferences, subjective experiences of the author and the information collected on reality is imbued with verisimilitude) and demographic and statistical data (whose harsh numbers require that their interpreters have a degree of sensitivity and knowledge of the context and social conjuncture that determines the movements of rising and falling of numbers and which does not cease to require a certain degree of

4 SANTOS, Flávio Gonçalves dos . "Tudo se revela diverso: a concessão, o movimento e problemas do Porto da Baía do Pontal - Ilhéus - Bahia (1911/1940)". In: CRUZ, M. C.V e; ANDRADE, M.G.L; PINHO, J. R.M.. (Org.). História e espaços portuário: Salvador e outros portos. Salvador - Bahia: EDUFBA, 2016. p. 173-188. Ourtranslation. 
"sociological imagination") 5 , the photographs (impressions of a time and space captured and frozen in record form) require attention to what pointed out Miton Guran:

the function of the photograph in the description is not necessarily to produce an exhaustive or redundant record in relation to the written information. Its contribution lies in the ability to make a selection of relevant aspects and significant moments of the reality studied, which could highlight information that could not be obtained by other means. $^{6}$

In order to prevent the text from being overloaded with graphic elements, we opted for the election of two sets of images, which allow us to see occupations and areas of work that were directly or indirectly linked to port activities or connected to the sea based on their interpretations.

\section{Two paths...}

The literary tradition of the South region of Bahia, which undoubtedly gained national and international support, was not alien to the organization of the Port of Ilhéus and the social phenomena that its presence would stimulate. Adonias Filho, in his novel Luanda, Beira, Bahia created an almost nostalgic image of Ilhéus from previous centuries. In a very interesting part of the novel, the author gives a description of what Ilhéus would be, and more specifically its port area, a hundred or two hundred years ago.

5 MILLS, C. W. A imaginação sociológica. 6. ed. Rio de Janeiro, RJ: Zahar, 1982pp.o9-32.

6GURAN, Milton. A “fotografia eficiente" e as Ciências Sociais. In: ACHUTTI, Luiz Eduardo Robinson (org.). Sobre o fotográfico. Porto Alegre: Prefeitura da Cidade de Porto Alegre; Unidade Editorial, 1998. p. 89. Our translation. 
"Year impossible to know[precisely], perhaps a hundred or two hundred years, would have seen the beach still virgin jungle, the Pontal with three huts and Ilhéus without the port. Canoes, oars in the hands of slaves and Indians, the sea with the serenity of a lake. The lanterns on the other side, the lighthouse was gone, forests still covered the hills. The bells called, just before nightfall, for the priests' prayers. Whoever brought it, simple seedling into a piece of bamboo, and planted it so close to the beach, you will never know".?

This is a fictional testimony, which from logical inferences and information obtained can reconstitute the plausible scenario that it wanted to portray. That is, that of a colonial society, with little or no urbanization. However, this strategy highlights what will follow, throughout the pages of the novel, a society whichbecause of its port became urban and transnational. Itsa scenario for narrating the adventures and tragedies of men and women who inhabited the port areas of Ilhéus.

Adonias Filho proposed a dichotomy and a synthesis of what was produced in the society of Ilhéus with the arrival of the port, lived by its main character, Caula.

Powerfully attracted by the sea, the protagonist of the novel, in his genealogy - son of a Portuguese sailor and an Indian from Olivença - marks what the author understood as the working alternatives for the poor people of Ilhéus. Going to the sea, integrating the great Atlantic commercial circuit or to go by the earth, dedicating oneself to subsistence agriculture, such as the planting of cassava and the commerce of piaçava, flour and cacao. After a brief passage through the service tradeof a shoemaker's apprentice, the character ended up fulfilling his destiny by throwing himself into the sea and taking his fortunes and misadventures from one side of the Atlantic ocean.

The interesting thing about this novel is that it evidences the lives and expectations of poor people and, in some way, the presence and lack ofhope relative to the sea. In the pages where Adonias Filho

7 FILHO, A. Luanda Beira Bahia. 15. ed. Rio de Janeiro: Bertrand Brasil, 1997, p.3. Our translation. 
decides the plot, held in Ilhéus, the author reveals a society that had a culture focused on the sea, but also deeply dependent on its agrarian culture. For it was in search of cacao that foreign ships arrived in the city and allowed the "men of Ilhéus" to be in the Atlantic, in the condition of long-haul sailors, cabotage, or fishermen.

The fact is that the alternative of being in the Atlantic became more forceful due to the organization of the port of Ilhéus, although it could have existed before it, and even more with long course navigation and the increase in the amount of vessels dedicated to great cabotage. The small cabotage, made by saveiros and sailboats, as well as fishing activity, are then no longer the main alternative for obtaining sustenance through the sea, and they were also an option for those who were not willing or could not live on the agriculture, trade or the provision of urban services.

The men of Ilhéus, in Pontal and Malhado, had only two paths - two paths and nothing else. They entered the woods into the womb of the jungles, or they went out to the harbors of the world. They preferred the sea, the whites and the blacks, those of Portuguese and African blood, while the caboclos of Indigenous blood chose the sertões. ${ }^{8}$

However, what is the extent of this dichotomy and synthesis? What did cocoa and port represent?

\section{3. "Prosperity, abundance, a lot of money..."}

"They were talking about the harvest by announcing it as exceptional, far surpassing all previous ones. With cocoa prices constantly rising, it meant even greater wealth, prosperity, abundance, a lot of money. The sons of the colonels went to the most expensive colleges of the big cities, new homes for the families in the newly opened streets, lu-

8 Idem, p.13. Our translation. 
xury furniture sent from Rio [de Janeiro], grand pianos to furnish the rooms, various shops multiplying, commerce growing, constant movement of drinksin cabarets, women disembarking ships, the game championing in the bars and in the hotels, progress finally, the so spoken civilization."

Thus, in the first few pages of "Gabriela, cravo e canela", the meaning of cocoa is announced for the Southern Region of Bahia. The novel is set in the city of Ilhéus between 1925 and 1926 and its narrative revolves around the idea that the Cocoa Region would eventually integrate with civilization and modernity. It marked this fact as a rite of passage, both because of the arrival of the port and the change of attitude in the city, in terms of morality and justice, with the punishment of a murder committed "in the name of honor". ${ }^{10}$

The choice of this moment to build the narrative is based on two concrete facts. The first was that the cocoa crop of 1925-26 placed Brazil, and therefore the Southern Bahia region, as the second world producer of cocoa beans. The second fact is that in 1926, part of this production reached the international market without the interferencefrom the Port of Salvador. On January 26 of that same year, the Port of Ilhéus "received for the first time a long course ship. It was the Swedish freighter named 'Falco', measuring 100 meters, which left carrying 47,150 sacks of cacao, destined to New York". ${ }^{11}$

The way Jorge Amado suggests the idea of progress and civilization point to a use of resources derived from cocoa production, in a wasteful and carefree manner. The consumption of luxury goods and services, gambling and prostitution are said to be the synthesis

\footnotetext{
9 AMADO, Jorge. Gabriela Crava e Canela: crônicas de uma cidade do interior. São Paulo: Companhiadas Letras, 2008, p. 17. Ourtranslation.

10 Idem, passin.

11 ROSADO, Rita de Cássia Santana de Carvalho. Cronologia portos da Bahia. Salvador: CODEBA, 1988 , p. 52.
} 
of what was understood by progress and civilization, which is only a partial truth.

The novel also reveals, through the conflict between MundinhoFalcão and Coronel Ramiro Bastos, the resistance of important economic sectors of the region against the implementation of an organized port, since it would represent the emergence of new characters to dispute the economic control and political power with the local oligarchy. These new characters were, in the novel and in real life, perceived by the old oligarchy as adventurers in search of easy fortune.

At the beginning of the twentieth century, the influx of resources to the region of South Bahia and the opportunity for good prices for cocoa in the international market highlighted the fact that production routes were far from ideal. The anchorage that was functional until the end of the 19th century began to present severe limitations. The regularity and transportation capacity of the LloydeBrasileiro and Baiana Shipping Company vessels, as well as the mediation of the port of Salvador in the export process of the product were understood as risks and limits to the expansion of the cocoa plantations. ${ }^{12}$

The transport of crops from the plantations to the shipment site was very precarious. It was providedby troops of mules and canoes. These means of transport, in addition to being very time consuming, interfered in the final quality of the product that was at the mercy of the weather, robberies and various damages. It was imperative that the cacao arrived at the port and then proceeded to export in less time, with less risk and without loss of quality. These needs opened up new areas for the emergence of economic sectors that until then had not been attracted to the South of Bahia.

It was necessary to ensure a good path between the producing areas and the outlet point. Thus, in 1904, a group of businessmen-

12 "The transport of goods to Bahia was done by two small yachts only, which traveled loaded to the point of having cargo up to the deck, subject to failure. Freights were 100 to 160 reis per arroba. But there were large ships from Alagoas and Rio de Janeiro carrying wood in the ports of the region". SILVA CAMPOS, João da. Crônicas da Capitania de São Jorge dos Ilhéus. Ilhéus: EDITUS, 2006, p. 377. 
connectedto the English capital pleaded and obtained the concession of the right of construction and exploration of the Railroad Ilhéus/ Conquista. ${ }^{13}$ The complete stretch of the railroad was never completed. Its total extension did not reach $100 \mathrm{~km}$, but it fulfilled well the role of interconnecting the cocoa producing area to the portas a kind of micro corridor for exportation. With the concession of the railroad approved, the next step for the group of national and international investors mobilized by Bento Berilo de Oliveira was the granting of the port concession in 1923. ${ }^{14}$ In 1911 the Railroad Ilhéus-Conquista was already operational and the first shipments of cocoa that left the organized port were made in 1926.

"Civilization" and "progress" arrived in the South of Bahia moved by the golden fruit. The city had a cosmopolitan feeling, attracting migrants and immigrants of all sorts, from the retreatants escaping from the droughts of the northeast to representatives of the great international capitals (English, French, German), passing through to the Syrians and the Lebanese who escaped from the Turkish-Ottoman Empire.

Ilhéus was no longer living only of cassava roots and piaçava due to the cacao and the port, which allowed an increasing influx of people and business opportunities.

The history of cocoa and its economic importance as well as the social phenomena that it produced have already been the object of attention in important studies, which revealed the dynamics of the implementation of this productive activity in the South of Bahia. ${ }^{15}$ These studies identified and discussed social phenomena such as

13 BORGES DE BARROS, Francisco. Memórias sobre o município de Ilhéus. Ilhéus: EDITUS, 2004, p. 107. 14 Brazil, Law 4,632 ofjanuary 6, 1923.

15See: GARCEZ, Angelina Nobre Rolim; FREITAS, Antônio Fernando G. de. Bahia cacaueira: um estudo de história recente. Salvador: UFBA, 1979. 108p (Estudos baianos; n.11); GARCEZ, Angelina Nobre Rolim; FREITAS, Antonio Fernando Guerreiro de. História econômica e social da região cacaueira. Rio de Janeiro: Carto-Gráfica Cruzeiro do Sul, 1975. FALCON, Gustavo. Os coronéis do cacau. Salvador: UFBA, Ianama, 1995; SANTOS, Milton. Zona do cacau: introdução ao estudo geográfico. Salvador: Artes Gráficas, 1955. 112 p. 
clientelism and coronelismo, which, stimulated by a republic recently enacted by landowners and militaries in repression of the abolition of slavery, marked the political and social relations of a region that after many centuries experienced the taste of certain prosperity. As a result of this process, the occupation and exploitation of land in the South of Bahia occurred in an authoritarian manner, mainly because it incorporated indigenous lands or lands already occupied by squatters, mostly ex-captives, almost always displaced in a violent way. ${ }^{16}$ Driven by the truculence and the success of Bahia exports, the frontiers of cocoa farming were extended. Lands of Indians, quilombolas and poor peasants were "opened by fire and sword" in the name of the progress and civilization of Ilhéus.

As a result of this process, the increase in cocoa production was less due to the improvement of management techniques and much more due to the incorporation of new lands to the crop. The effects of the occupancy process of new areas can be analyzed in Graph 1. From this, it is possible to compare the performance of cocoa in relation to the other agricultural products of export from Bahia in the period between 1869 and 1880. The contribution of cocoa was less than $5 \%$ in most of the period. However, from $1874-75$ it is possible to perceive an uptrend, remaining until the end of the period, with a share of more than $5 \%$ and the maintenance of an ascension movement.

In this period, the performance of cocoa was not comparable to the importance of tobacco or coffee. Sugar, tobacco and coffee were the three main export products of Bahia. However, sugar registered a consistent downward movement, dropping from a 30\% share of exports at the beginning of the period to a share of less than $25 \%$ at the end of the period. On the other hand, Tobacco presented an inverse movement, going from a participation of less than $30 \%$, reaching $40 \%$

16 Mahony, Mary Ann. Afro-Brazilians, Land Reform, and the Question of Social Mobility in Southern Bahia, 1880-1920. Luso-Brazilian Review, v. 34, n. 2,p. 59-79, Winter 1997, ; CRUZ, Ronaldo Lima da. "Conflitos e tensões : conquistas de escravizados e libertos no sul da Bahia (1880-1900)". Franca : Dissertação (Mestrado em História). Universidade Estadual Paulista. Faculdade de Ciências Humanas e Sociais. 2012. 
in the interval of 1879-79, but falling soon after, reaching a participation of $35 \%$ in Bahia's exports. It is worth mentioning, with regard to the end of the period recorded in Graph 1, that only coffee and cocoa presented a growth trend.

\section{Graph I}

\section{Products share the Bahian exports (in \%)}

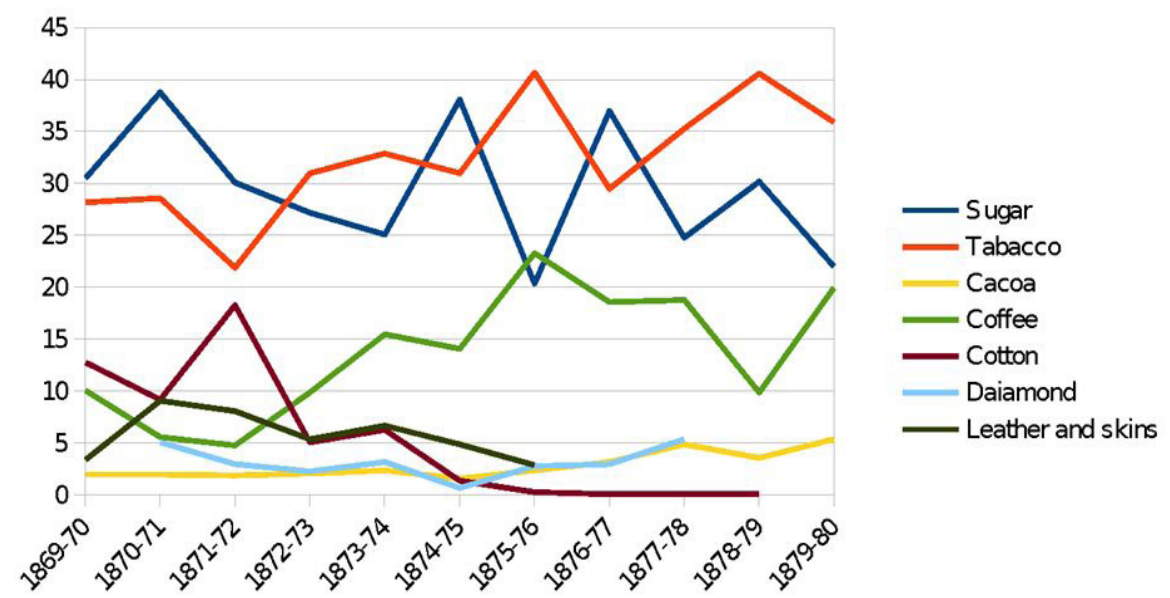

Source: Proposal and reports presented to the Legislative General Chamber by the Ministers and Secretaries of State for Finance, Rio de Janeiro (1852-1888); discussionby the

Presidents of the Province of Bahia, 1851-1889; Calculations GTEP/CPE. Adaptation of a table found in the Research Foundation-CPE, 1978, p. 24.

(Productive Activities).

Observing the latest period through the data of Graph 2, it is possible to verity the evolution of the previous scenario. The trend of slow and gradual increase in the importance of cocoa in the export agenda remained, the period beginning with a contribution almost $10 \%$ of the revenue from exports, remaining below this percentage until 1884-85, falling again in the biennium of 1886-87. Sugar maintained the downward trend of the previous period and reached the end of the biennium 1888-89 with almost no participation. It is important to note the lack of data on its share of Bahia's export revenue, 
in the period from 1878 to 1881 . However, this fact does not prevent identification of its loss of economic importance. In the years 188889, the fiasco of sugar performance in Bahia exports is remarkable. However, it must be considered that these years were emblematic for the political and economic history of the country, with the prospect of abolishing slavery and the subsequent Proclamation of the Republic, with a direct impact on sugar production.

Tobacco maintained the downward trend shown in Graph 1 and, as can be seen in Chart 2, it increased in the following period, from 1878 to 1889 . From 1887 it suffered a sudden downward movement, falling approximately from $37 \%$ to something around $17 \%$ in its contribution to Bahia's export revenues.

All Bahia exports at the end of the period showed a sharp drop, with the exception of coffee, which kept its upward trend. From the biennium of 1886-87 to the biennium of 1888-89, coffee jumped from a participation of approximately $20 \%$ to a share of over $50 \%$ of revenue. That is, the end of compulsory labor and the imperial government did not have the same impact on the coffee plantations as it exerted on the other agricultural commodities of Bahia. One may even suppose that coffee from Bahia has benefited from the impact of these historical events in other producing regions of the country. 


\section{Graph II}

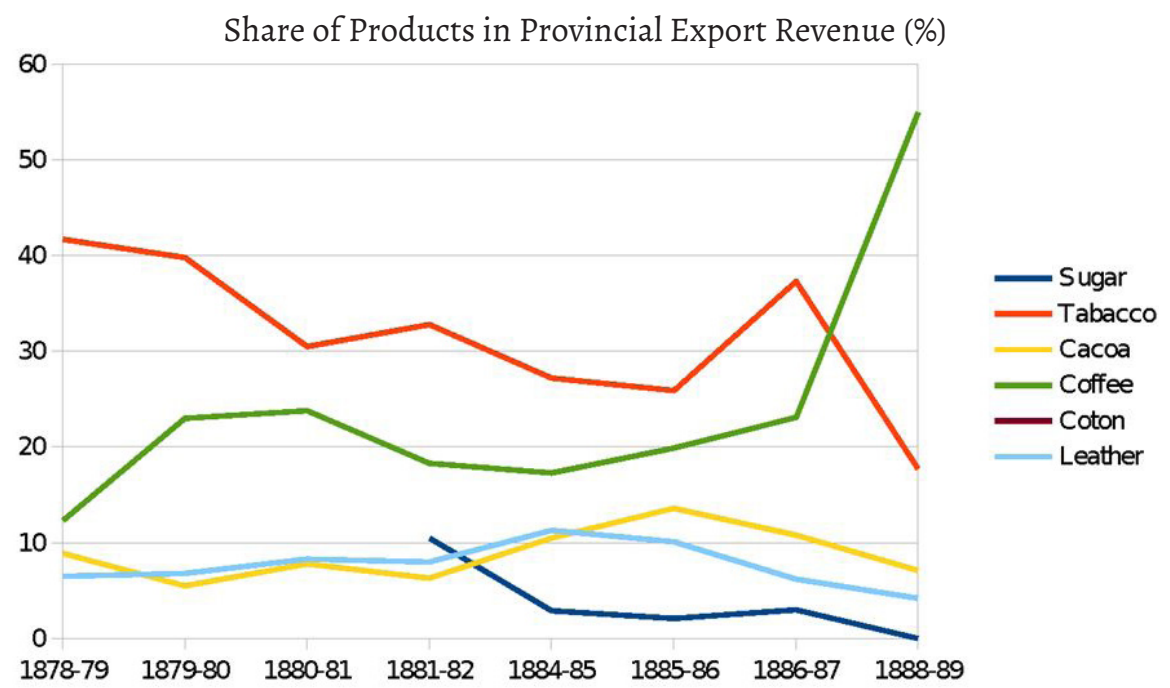

Source: Adaptation of a table found in the Research Foundation-CPE, 1978, p. 29.

(Productive Activities).

In the next scenario, illustrated by Graph 3, it can be seen that cocoa was gaining importance compared to other products. Sugar kept its downward trend. Only after 1900 it showed a tendency of ascension that remained constant until 1930. After a period of decline, coffee resumed in the second decade of the twentieth century with a consistent movement to increase participation in the foreign trade agenda of Bahia. The tobacco and cocoa that showed a growth movement also from the decade 1911-1920 increase in the volume of exports.

With regard to this upward movement, it is possible to understand the influence of the demands created by the First World War. For cacao, in addition to this fact, it is possible to add to the improvement of production flow conditions, especially with the installation of a railway line to improve port facilities in Ilhéus. The first began in 1905 and the second began in 1911. 


\section{Graph III}

Export by Product - Bahia/1899-1930 (in Contos de Réis)

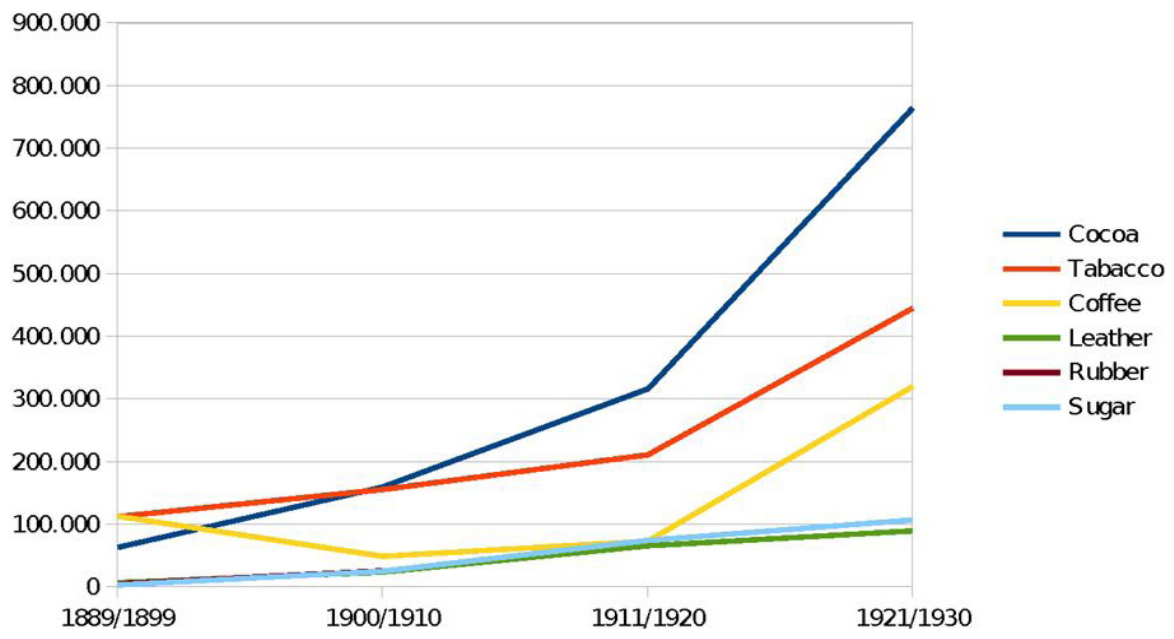

SOURCE: Foundation Research Center. Op. Cit. Pp.120-121.

In summary, Graphs 1, 2 and 3 demonstrate the evolution of the importance of cocoa to the economy of Bahia, to the point of becoming the main source of resources for the region. In addition, part of the income obtained from exports were available for investment in roads and means of transportation, with a fairly guaranteed return perspective.

It is unquestionable that the improvement of access routes and means of transporting products acted as a catalyst for the performance of cocoa production, as it made the product even more accessible to international markets, whereas having good prices stimulated the increase in production, which consequently resulted in the integration of new areas to the farming.

The incorporation of these new areas turnedIlhéusinto a confluence point for farm production in areas that currently belong to municipalities such as Itabuna, Itajuípe, Itacaré, Uruçuca, Ubaitaba, Itapé, Ibirapitanga, Pau Brasil, Camacã, Buerarema and others. This 
granted Ilhéusthe role of regional political and economic leadership, a kind of showcase of the Cacao Region. ${ }^{17}$

Although not everything was rigorously planned and rationally executed, it is undeniable that the railroad and the port altered the features of the city, stimulated the emergence of new economic activities, and instituted a way of life that was unprecedented in the region at that time of the twentieth century. However, it is necessary to consider the contributions of M. H. Dias, who, contrary to the theory of isolation and economic stagnation of the Captaincy of Ilhéus, reveals the existence of an active coastal navigation circuit driven by the trade of flour and noble wood, although not exclusively for that. ${ }^{18}$ According to this author:

The organization of a steady flow of the product [flour] to the capital for so many years contributed to consolidate the integration of the Captaincy of Ilhéus into a significant regional market. In this way, a sufficient demand was guaranteed to maintain a level of capital circulation capable of stimulating the expansion of the agricultural frontier and the reproduction of the slave system in its better-equipped productive zones. ${ }^{19}$

Although the categories chosen by the author and borrowed from Russel-Wood to qualify the type and degree of relationship with the capital Salvador may result in more debate than clarification, he succeeds in demonstrating that the District of Ilhéus was not economically isolated. ${ }^{20}$ Especially if we compare the case of Ilhéus, for

17 BAHIA. Annuário Estatístico Annos de 1924-1925. Vol. II. Salvador: ImpresaOfficial do Estado, 1926, p. 27.

18DIAS, Marcelo Henrique. Farinha, madeiras e cabotagem: a Capitania de Ilhéus no antigo sistema colonial. Ilhéus: Editus, 2011.

19Idem, p. 102. Our translation.

20 The author rightly characterizes the relationship of the District of Ilhéus and the City of Salvador as the type center-periphery. However, the use of the term umland, used by Russel-Wood to characterize the relationship model established between the two, bears little relation to the 
example, to the case of Minas Velha (present City of Rio de Contas) analyzed by Marvin Harry and with a considerable analytical contribution of Fernand Braudel ${ }^{21}$. They have focused on how a community in Bahia, whose moment of prosperity occurred in the eighteenth century, could survive in the mid-twentieth century with an almost stagnant economy,being on the margins of any more dynamic economy. And it was able to create within its possibilities an economic circuit of its own from the "field-city" relationship, avoiding its disappearance. As pointed out by Braudel:

Minas can only rely on the work of its craftsmen: copper craftsmen, blacksmiths, as well as saw, harness and baggage makers, lace and flowers, handicrafts, tinkers, weavers, seamstresses and tailors, carpenters. Imagine a medieval, small town that works for its own market and, when it can, trades far and wide. The near market is the peasants [...] who buy saddles, knifes, harnesses and whips ... the distant market, par excellence, the zone of donkey circulation [...]. This market goes west until Xiquexique, until the pilgrimage of Bom Jesus da Lapa, on the São Francisco River, pilgrimage and fair at the same time.22

In fact, Ilhéus never experienced a similar situation, even before the cocoa or the organization of its port, because there was an economy that involved other productive and commercial circuits, although not with the same relevance of what was installed after the cocoa.

It is evident that the influx of capital in the Southern region of Bahia from the cocoa export trade was a watershed for the city of

usual use of terms, whether in the field of geography or in the field of logistics, or even in the meaning these expressions have in German, their linguistic trunk of origin. For the Captaincy of Ilhéus, it must be considered that it was another administrative and territorial unit, and it is therefore necessary to consider this relationship of dependence in other aspects besides a supposed geographical, climatic and cultural continuum.

21HARRYS Marvin. Town and Country in Brazil, Columbia University Press, 1956 e BRAUDEL, Fernand. Escritos sobre a história. 2.ed. São Paulo: Perspectiva, 2005.p. 219-233.

22 BRAUDEL. Op. Cit. p. 225. Our translation. 
Ilhéus. Although it has never ceased to integrate an active economic circuit, it hada short time interval in a dynamic economic pole capable of attracting investments to carry out major infrastructure work, such as the construction of a railroad and the transformation of an anchorage of cabotage navigation into an organized port, ready to receive boats of long course.

But what represented the existence of this organized port for Ilhéus? ${ }^{23}$

\section{What do the censuses tell us?}

In 1872, for example, the Parish of São Jorge dos Ilhéus had a population of 5,682 inhabitants, distributed in 1029 fires (or houses). As of 1920, the Municipality of Ilhéus was composed of six districts, Ilhéus, the main city; Aritagua, Cachoeira de Itabuna, Castelo Novo, Banco do Pedro and Pontal. The total population was 63,012 inhabitants and a population density of 7.24 inhabitants per square kilometer. It had about 8,534 occupied homes and 534 unemployed; 1 hospital; 8 schools, 7 in headquarters and 1 in Pontal; 103 farms and 173 business houses. This means that, in 48 years, the demographic density and urbanization of the municipality grew significantly, and this process finds in the expansion of the cacao farming one of its motivators.

This is general data of the population growth of Ilhéus. However, if we take as a reference, for example, the Census data of 1872 , 1920 and 1940, we can make an approximate idea on the evolution of paid employment options for men and women. Before, during and after the installation of the organized port of Ilhéus.

23 The impact of the port on the landscape of the city, although the theme is far from being exhausted, has already been object of attention in another text, namely: SANTOS, Fávio Gonçalves dos. "A Baía do Pontal - Ilhéus: relações do porto com a cidade (1911-1971)" in Revista Crítica Histórica, ano VII, n. 13, junho/2016 
Noting the population composition of Ilhéus in terms of sex and legal status, according to Census data from 1872, it is observed that approximately $17 \%$ of the population was enslaved, a total of 1050 people. Of these, 718 were declared as farmers, 117 as domestic workers, and 185 were declared as having no defined occupation. For the manual or mechanical professions, the presence of slaves was small, totaling 31 people distributed as follows:
a) among the 17 metalworkers, six were enslaved men;
b) among the 55 workers who worked with wood, 12 were enslaved men;
c) among the 5 workers who worked with buildings, I was an enslaved man;
d) among the 10 workers who worked with shoes, 1 was an enslaved man;
e) among the 197 seamstresses, 11 were enslaved women. ${ }^{24}$

24 Brasil. Recenseamento do Brazil em 1872. Vol. 3 - Bahia. Rio de Janeiro: Typ. G. Leuzinger, 1874, p.279. 


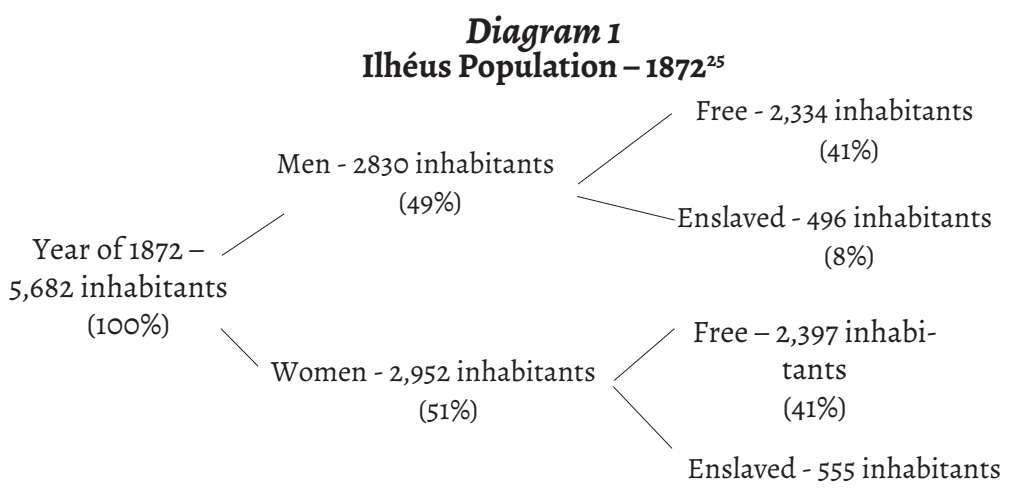

(9\%)

Among the free workers, the majority were in the field, 2,613 people were declared as farmers. In second place were those declared without profession, being a total of 1,241 people. ${ }^{26}$

Among the occupations that are directly linked to the port and shipping, such as seafarers and fishermen, the census counted 13 men dedicating themselves to the first and 39 to the second. Women and slaves, as the document indicates, were not engaged in these activities. ${ }^{27}$

It is possible to conclude, however, that by the 1870 s around $58 \%$ of the inhabitants of Ilhéus were rural workers; $23 \%$ of the population did not have a declaredprofession and only $0.9 \%$ were involved in some activity immediately linked to the sea. ${ }^{28}$

Between 1872 and 1920, that is in less than 50 years, the population of Ilhéus increased eleven times its size, going from 5862 inhabitants to 63,012 inhabitants according to the demographic census data of the respective years. ${ }^{29}$

25 Idem.

26 Idem, Loc. Cit.

27 Idem, Loc. Cit.

28 Idem, Loc. Cit.

29BRASIL. Recenseamento do Brazil :realizado em 1 de setembro de 1920.. Rio de Janeiro: Typ. da

Estatística, 1928.v. V, Tomo 1.p. 298. 


\section{Diagram 2 \\ Ilhéus Population - $1920^{30}$}

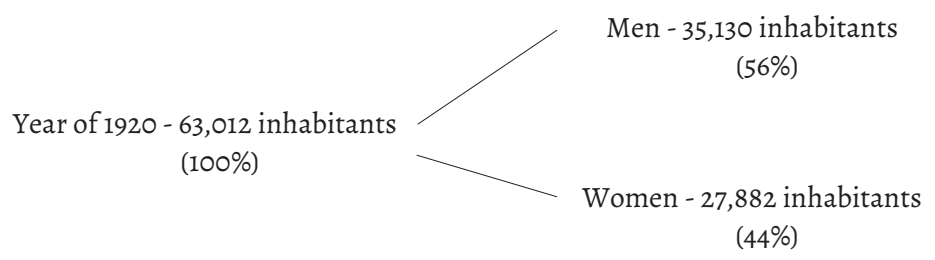

Observing the population composition of Ilhéus by sex according to data from the 1920 Census, approximately $44 \%$ of the population was female and 56\% male. Of this amount, 21,763 men were declared as having a defined occupation, against 13,367 who were registered as without profession. Among women, 2,472 had some type of occupation and 25,410 were unmarried. Of the total number of men and women who were indicated without a defined occupation, a significant portion of the population aged 0 to 14 years and 15 to 20 years, that is, that was not completely economically active.

Among those over the age of 21 , the discrepancy between men and women declared as without profession is very large and reveals how undervalued women were in their labor and productive activities. Only 593 men over the age of 21 were declared as without profession, while 9,922 women over the age of 21 were included in this situation. This means that $33 \%$ of women of economically active age or $14 \%$ of the population of Ilhéus in 1920 apparently did not have their occupation recognized. ${ }^{31}$

Among the main labor activities declared are professions in Agriculture, Commerce, Building, Clothing and Toilet Services, Domestic Services and Maritime, wherein to the latter can also be added the military of the Navy.

30 Idem, Loc. Cit.

31 Idem, Loc. Cit. 
In spite of the increase in population and also of the number of occupations found in Ilhéus, compared to 1872, the majority of the population still derived their livelihood from agriculture. There were 14,690 people in the field, as farmers, 13,508 of whom were males and 1,182 females. In both cases the majority of workers were over the age of 21 .

Between the occupations that are directly related to the port and the navigation, such as seafarers and fishermen, the census counted 471 men enrolled as seafarers and fishermen, 15 as military linked to Navy of Brazil, and 52 more dedicating themselves to the activity of hunting and fishing.

From the analysis of these data, it is plausible to conclude that by the 1920 s, $23 \%$ of the inhabitants of Ilhéus were rural workers; $61 \%$ of the population, i.e., 38,777 people, had no declared profession. And that the number of people involved in some activity immediately linked to the sea increased in absolute terms, but maintained the same percentage index from 1872, that is, of $0.9 \%$ compared to the total population.

\section{Table 1}

Partial sample of occupations in Ilhéus according to the Census of 1920

\begin{tabular}{|c|c|c|c|c|c|c|c|}
\hline & $\begin{array}{c}\text { Agricul- } \\
\text { ture }\end{array}$ & Trade & $\begin{array}{c}\text { Build- } \\
\text { ings }\end{array}$ & $\begin{array}{c}\text { Clothing } \\
\text { and Toilet- } \\
\text { ries }\end{array}$ & $\begin{array}{c}\text { Do- } \\
\text { mestic } \\
\text { Services }\end{array}$ & $\begin{array}{c}\text { Mariners } \\
\text { and } \\
\text { Sailors }\end{array}$ & $\begin{array}{c}\text { Fisher- } \\
\text { men }\end{array}$ \\
\hline Totals & 14.690 & 948 & 880 & 928 & 548 & 486 & 52 \\
\hline Men & 13.508 & 924 & 880 & 352 & 145 & 486 & 52 \\
\hline O-21 years & 2393 & 115 & 122 & 80 & 55 & 67 & 6 \\
\hline+21 years & 11.116 & 809 & 758 & 272 & 90 & 419 & 46 \\
\hline Women & 1.182 & 25 & - & 586 & 403 & - & - \\
\hline O-21 years & 249 & 2 & - & 111 & 125 & - & - \\
\hline+21 years & 933 & 23 & - & 465 & 278 & - & - \\
\hline
\end{tabular}

Source: Brazil. Recenseamento do Brazil: realizado em 1 de setembro de 1920 . Vol. V, Parte, Tomo 1. Rio de Janeiro: Typ. da Estatística, 1928, pp. 298-299. 
In 1940, Ilhéus had a population of 113,269 people, of which 62,385 were men and 51,384 were women. Of these, 31997 people were declared to be related to domestic or school activities, of which 29,283 are women and 2,714 are men in this field. Another group in which a series of disparate situations were grouped also added a significant number of people, such as: inactivity, badly defined activities, not fittting the other areas. In this situation were declared 8,160 people, being 4,330 men and 3,830 women. ${ }^{32}$

According to data from the 1940 Census, 28,191 people were engaged in agricultural occupations (agriculture, livestock and forestry), 27,071 being males and 1,120 females. For the "Services, Social Activities" sector, 4,044 people were declared, of which 2,221 were men and 1,823 women. A total of 3,080 people dedicated to the manufacturing industry, of which 2948 were men and 132 women. Trade occupied a total of 2,594 people, of which 2,459 were men and 135 women.

In this edition of the census, descriptions of the labor activities were grouped by area of work in such a way that the visualization of the number of workers in maritime or port activities could not be estimated with precision. For the "Transport, Communication" activities area, 1633 people were declared, of which 1620 were men and 13 women. Looking at the data from the 1920 Census and grouping them by the same criteria, we would have the following scenario:

\section{Table 2}

Number of people employed in Transport and communication ${ }^{33}$

\begin{tabular}{|c|c|c|c|}
\hline Census & Men & Women & Total \\
\hline 1920 & 584 & 3 & 587 \\
\hline 1940 & 1,620 & 13 & 1,633 \\
\hline
\end{tabular}

32 BRASIL. Recenseamento geral do Brasil 1940: realizado em 1 de setembro de 1920. Série Regional.Parte XII, Tomo 1.Serviço Gráfico do IBGE, 1950.

33 Idem. 
From these data, and with the warning that the categories of occupation are grouped in a way that the number of workers bound to the sea and the port of Ilhéus cannot be accurately stated, it is still possible to affirm that, over the course of 20 years, there was a duplication of work positions related to transport and communication. There was an increase of $33 \%$ in occupations related to this area of activity, that is, $1.4 \%$ of the population was working with transportation and communication.

It can be taken as reference that the percentage of $0.9 \%$ of the total population of Ilhéus was linked to activities related to the sea or port in 1940, as observed in the censuses of 1872 and 1920. The maximum quantity one could possibly arrive atwould be approximately 1019 people.

However, to illustrate the situation better one could say, for instance, that the Companhia Industrial de Ilhéus did not equip its port with cranes, but had as a means of transportation 90 handcarts, with the capacity of up to 4 bags of $60 \mathrm{~kg}$ each. One must then assume that the company had a workforce of at least 90 shippers in times of greatest need. Another factor to consider is the presence of the trade union organization. There were at least three trade unions linked to port workers. ${ }^{34}$

So far it has been shown that there has effectively been an increase in absolute numbers of people involved with port and maritime activities from 1872 to 1940 . And more than that, in the interval between 1920 and 1940, only taking into account the period of organization and full operation of the organized port of Ilhéus, there was an increase in the absolute number of people involved with occupations related to the Transport and Communication activity area. Thus, it can be inferred that there was also an increase in the number of work positions related to maritime and port activity. However, the nature of

34 See:CARVALHO, PhilipeMurillo Santana de. "Trabalhadores, associativismo e política no sul da Bahia (Ilhéus e Itabuna, 1918-1934)". Salvador: Universidade Federal da Bahia. Faculdade de Filosofia e Ciências Humanas. Programa de Pós-Graduação em História Social. 2015. 
port work in this period, especially that of stevedoring and shippers, make it difficult to count and identify these workers based on demographic census data. They were independent workers, so it is possible that many were included in the categories of workers without a defined or declared profession in the censuses of 1920 and 1940.

Another document, also of statistical nature, reports that in 1939, in Bahia, there were 20,367 people enrolled in the Captaincy of Portos, distributed among the categories of Mariners (15,336), MarinerAssistants (657), Fishermen $(2,935)$ and Stevedores $(1,439)$, distributed between the Organized Ports of Salvador and Ilhéus, also being likely to occur in the anchorages (or small cabotage ports) of Canavieiras, Caravelas, Prado and Alcobaça. ${ }^{35}$

The limitations of the censuses are clear. So what would other sources say?

\section{What do the photographs show?}

If a historian was given the opportunity to travel in time and transfer to the time of his/her object of study, it is possible that he/ she would pay less attention to numbers and written words and had his/her attention drawn to the scenes of daily life that he would witness. This being obviously impossible, he/she can approach this possibility from iconographic registers - paintings, drawings and photographs. Of course, there are issues caused by mediatedperspective, which always differ from direct observation, but this issue is posed for any source.

35 BRASIL. Sinopse Estatística da Estado da Bahia. Rio de Janeiro: Serviço Gráfico do IBGE, 1942.n. 4. p. 75 
When walking through the streets of Ilhéus around the year 1930, it would certainly not be uncommon to observe the scenes depicted in Figure 1.

We can deduct from them that the main concern of the person who produced the images was the bags of cocoa and the way they were being transported. In the first image - the largest that occupies half a page in its panoramic format - among the observers on the other side of the street, probably watching, the photographer carefully looks for the best framing of the donkey troop; there are children and clearly poor workers, who, for their costumes and hats, differ socially from another group in suit, tie and chapéu-palheta, the latter being very popular in Brazil between the years 1920 and 1940.

There are no women on the scene, which makes room for many digressions. The legend informs that the troop of muáres transports the cocoa to the port, so we can suppose that this image was taken in the port area of Ilhéus. But what it reveals in terms of occupation is that this troop was led by men over 21 years, and eventually young people between the ages of 15 and 20 . These tropeiros are probably independent workers, contracted by projects and without a clearly defined profession, transiting between diverse occupations in the field as in the city. Perhaps it was the poor observers on the other side of the street, unfocused and decentralized from the scene, in favor of muarés and cocoa sacks. 


\section{FIGURE I}

\section{Transport of Cocoa to the port of Ilhéus - around 1930}

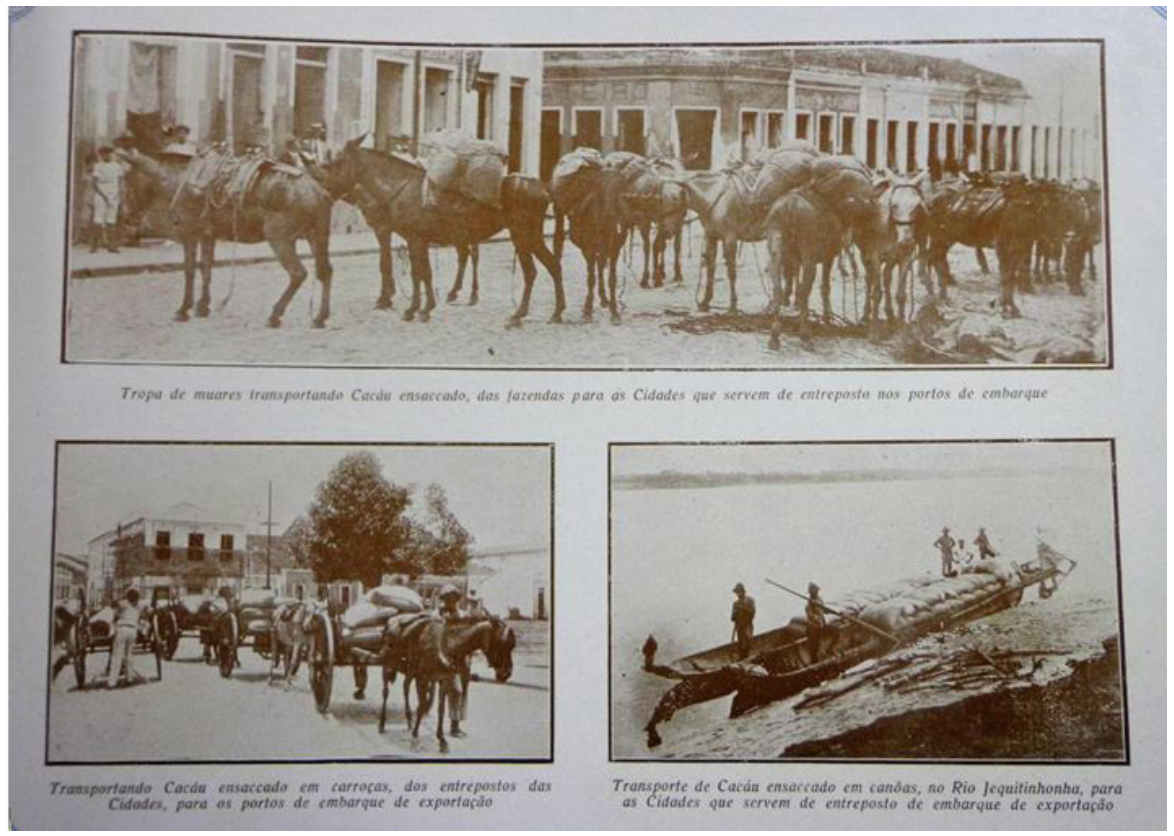

Source: FILGUEIRA, Manuel Rodriguez (org). Álbum Artístico, Commercial e Industrial do Estado da Bahia, 1930 - Biblioteca Pública do Estado da Bahia - BPEB.

The second photo, below to the left, registers another form of transport of cocoa, this time not in a troop of muáres, but in carts. It presents another professional category, the carters. In the recorded scene, there are also no women, whereas two men are clearly visible. One leading the cart, dressed in clothing typical of poor workers. His trousers were torn close to the knee, he wore what appears to be a slipper, and the felt hat is deformed by the sun and the rain. The other one is on his back, wearing light clothing, possibly white, shirt on the inside of his pants contrasting with a black belt. His attitude in the photo is of someone inspecting the loading of the wagon. Which allows the assumption that it is a trader or an employee of some commercial house. In the background, it is possible to perceive a house 
under construction, which could also reveal the presence of workers related to the Construction sector.

Finally, the third photograph of this set of images presents the crew with two canoes full of cacao. In it are six men, four of them in dark clothes, with hats deformed according to the fashion of the manual workers of the South of Bahia in the period of the photo. They are in a relaxed, almost inept attitude towards the photographer. The other two men are in light clothing, one with a hand at the waist posing for the photograph and the other, almost imperceptible by the quality of the image, taking the oar that acts as rudder in the stern of the first canoe. A fact that can also be interpreted as a pose for photography. These light-colored men could also be inspectors of canoe loads, acting professionally as traders or employees of commercial cacao-trading agencies.

In Figure 2, there is a set of photographs showing other categories of workers related to the port and the sea. The first in the upper left registers the shipment of cacao on a sailboat. Probably dedicated to small cabotage navigation. Eighteen men appear in the photographic record, mostly without shirts. Eight of them are lined up on a precarious wooden bridge carrying sacks of cocoa over their heads. Of these, four are wearing shirts and the other five are shirtless. They stand in line waiting their turn to board and unload their cargo. On-board the vessel are ten men. Two of them without a shirt, with the attitude of someone who unloaded his cargo and waits for the moment to return by the bridge. There's a man still with the sack on his head and seven others who seem to be watching the scene. Of these seven men who observe cocoa boarding, five of them appear to be wearing shirts. Among these, one is dressed in light clothing and wearing a cover that looks like a cap. His overall appearance suggests wearing some sort of uniform. His observing attitude, with his hands turned back in an almost martial position may denote some kind of authority. Perhaps it is the captain, the ship's immediate officer, or some representative of the port captaincy conferring the embarking of goods. From this interpretation of the photo, we can deduce the 
existence of at least three groups of occupations, the shippers, the sailors and some military police authority.

The second photograph of this set of images appears to be another sailboat record of the first photo already fully loaded. In the scene appear nine people: five adult men and four children. Three of the men are seated on the cargo, they are in pants and shirt, the shirts are clear, which suggests they are sailors or passengers. And two other men are standing. The one furthest from the photographer may not have his or her clothing clearly identified, but the nearest man appears to be in uniform, some kind of graduate crewmember, or uniformed passenger. His posture suggests he is relaxed,stepping on some structure of the boat and resting his arm on his leg. At his side are children,possibly passengers. Considering that these men are part of the crew, we can deduce an occupation related to the sea and the port of Ilhéus, the seafarers.

The third image, bottom left, features a cocoa boarding scene in the port of Ilhéus. In it, there are stevedores moving the cargo from the warehouses to the pier, where the loads will be taken from and accommodated on board by the ushers. This is an occupation that has always been related to independent work, that is, it is done by contracting and with great autonomy and organization of the workers. ${ }^{36}$

36 CRUZ, M. C.V. e. "Tradições negras na formação de um sindicato: Sociedade de Resistência dos Trabalhadores em Trapiche e Café, Rio de Janeiro, 1905-1930”. Afro-Ásia, n. 24, 2000, p. 243-290. 


\section{FIGURE II}

\section{Cocoa vessel going to the port of Ilhéus - around 1930}

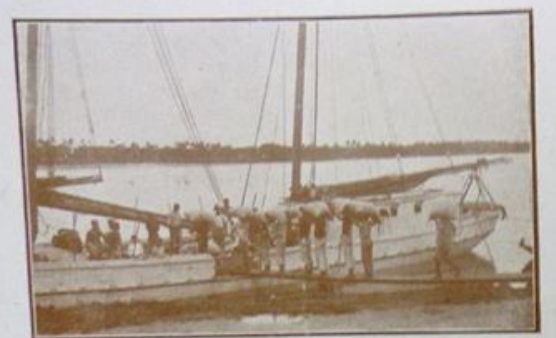

Finharuate de Cacda rm barregas, nov pertas do Sul do Estede, paro

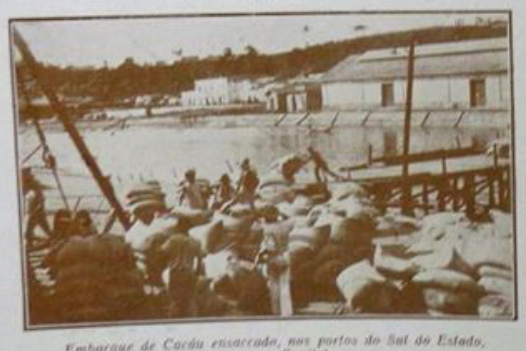

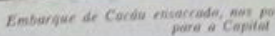

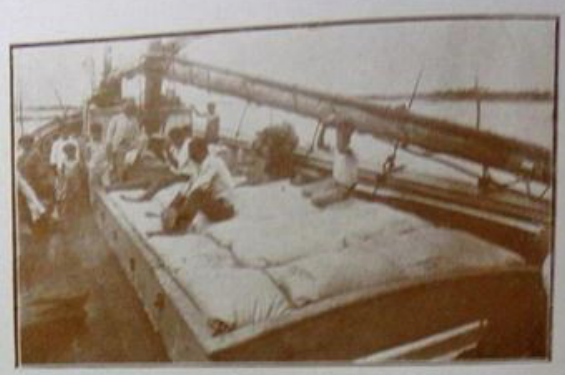

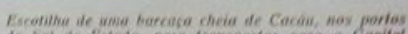
to Sat do Eutodo, fura transpartar para a Capital

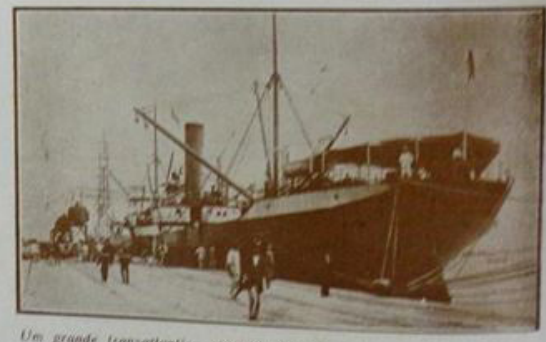

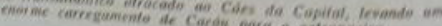

Source: FILGUEIRA, Manuel Rodriguez (org). Álbum Artístico, Commercial e Industrial do Estado da Bahia, 1930 - Biblioteca Pública do Estado da Bahia - BPEB.

This observational exercise of the photographic record with a perspectivedirected towards the presence of workers allowed to identify a set of occupations that were in fact related to the port and navigation. The images show that there were many professional categories that had in their daily work relations with the loading and unloading of cargo from the port. Many others can be revealed, expanding the amountof images analyzed. Although in statistical accounts, demographic census, statistical yearbooks and others, these workers may have been enrolled in other branches of work without any apparent relation with the Port of Ilhéus, it is undeniable that the 
existence of the port contributed to their sustenance in activities that were not necessarily related to work in the fields.

\section{Almost final considerations}

Two questions were raised throughout the article, the first being if the port introduced new branches of work in Ilhéus, and the second being how to identify which activities would be related to the port.

Thus, after the analysis of the sources, the following considerations were reached:

a) is undeniable that the Port of Ilhéus stimulated the emergence of new branches of occupation, from the capitalist who was attracted to the region in search of new investment opportunities, in the port and in the houses of commercial representation, to the workers, stevedores, tropeiros, shippers, carters and others, who in the port found the sacks they would carry and other merchandise that they unloaded and carried;

b) many categories of work, apparently linked to the other occupation areas, were also related to the Port, although their association with it was less immediate, such as the military, public representatives and private administration, tropeiros, carters, canoe workers, and others;

c) many workers were included in the census data as "No declared profession or No defined occupation", and thousands of women and men engaged in self-employment were included in that group.

Although the port has improved the dynamics of the economy, given its progress and constitution as another work option, the city of Ilhéus as a municipality remained essentially rural during the period analyzed. This fact is demonstrated by the census data. Of course it could not be otherwise, for all the wealth and prosperity experienced by the region, including the port, came from the cocoa plantations. 
Therefore, from the two paths pointed out by Adonias Filho - the forest or the sea, the most attractive was still the path of the forest.

\section{References}

AMADO, Jorge. Gabriela,crava e canela: crônicas de uma cidade do interior. São Paulo: Companhia das Letras, 2008.

ANDRADE, M.G.L; PINHO, J. R.M.. (Org.). História e espaços portuários: Salvador e outros portos. 1ed. Salvador - Bahia: EDUFBA, 2016.

BRAUDEL, Fernand. Escritos sobre a história. 2.ed. São Paulo: Perspectiva. 2005.

CARVALHO, PhilipeMurillo Santana de. Trabalhadores, associativismo e política no sul da Bahia (Ilhéus e Itabuna, 1918-1934). 2015. Tese (Doutorado em História Social) - Faculdade de Filosofia e Ciências Humanas, Universidade Federal da Bahia, Salvador, 2015.

CRUZ, M. C. V. e. Tradições negras na formação de um sindicato: Sociedade de Resistência dos Trabalhadores em Trapiche e Café, Rio de Janeiro, 1905-1930.Afro-Ásia, n. 24, p. 243-290, 2000.

CRUZ, Ronaldo Lima da. Conflitos e tensões: conquistas de escravizados e libertos no sul da Bahia (1880-1900). Franca: Dissertação (Mestrado em História) - Universidade Estadual Paulista. Faculdade de Ciências Humanas e Sociais, 2012.

DIAS, Marcelo Henrique. Farinha, madeiras e cabotagem: a Capitania de Ilhéus no antigo sistema colonial. Ilhéus: Editus, 2011.

FALCON, Gustavo. Os coronéis do cacau. Salvador: Ed. UFBA: Ianama, 1995.

FILHO, A. Luanda BeiraBahia. 15. ed. Rio de Janeiro: Bertrand Brasil, 1997.

GARCEZ, Angelina Nobre Rolim; FREITAS, Antônio Fernando G. de. Bahia cacaueira: um estudo de história recente. [Salvador]: UFBA, 1979. (Estudos baianos; n.11);

. História econômica e social da região cacaueira. Rio de Janeiro: Carto-Gráfica Cruzeiro do Sul, 1975.

GURAN, Milton. A "fotografia eficiente" e as Ciências Sociais. In: ACHUTTI, Luiz Eduardo Robinson (org.). Sobre o fotográfico. Porto Alegre: Prefeitura da Cidade de Porto Alegre: Unidade Editorial, 1998. p. 89.

HARRYS Marvin. Town and country in Brazil.New York: Columbia University 


\section{Press, 1956}

MAHONY, Mary Ann. Afro-Brazilians, land reform, and the question of social mobility in Southern Bahia, 1880-1920. Luso-Brazilian Review, Madison, WI, v. 34, n. 2, p. 59-79, Winter, 1997.

MILLS, C. W. A imaginação sociológica. 6. ed. Rio de Janeiro: Zahar, 1982.

ROSADO, Rita de Cássia Santana de Carvalho. Cronologia portos da Bahia. Salvador: CODEBA, 1988, p. 52.

SANTOS, Flávio Gonçalves. A Baía do Pontal - Ilhéus: relações do porto com a cidade (1911-1971). Crítica Histórica, Maceió, Ano VII, n. 13, jun. 2016.

. Tudo se revela diverso: a concessão, o movimento e problemas do Porto da Baía do Pontal - Ilhéus - Bahia (1911/1940). In: CRUZ, Maria Cecília Velasco; LEAL, Maria das Graças de Andrade; PINHO, José Ricardo Moreno (Orgs.). História e espaços portuários: Salvador e outros portos. Salvador: Ed. UFBA, 2016. p. 173-188.

\section{Sources}

BAHIA. Annuário Estatístico Annos de 1924-1925. Salvador: Imprensa Official do Estado, 1926. v. II. p. 27.

BORGES DE BARROS, Francisco. Memórias sobre o município de Ilhéus. Ilhéus: Editus, 2004. p. 107.

BRASIL.Recenseamento do Brazil: realizado em 1 de setembro de 1920.. Rio de Janeiro: Typ. da Estatística, 1928. v. 5, Tomo 1.

BRASIL. Recenseamento do Brazil em 1872. Rio de Janeiro: Typ. G. Leuzinger, 1874. v. 3 - Bahia.

BRASIL. Recenseamento geral do Brasil 1940: realizado em I de setembro de 1920. Série Regional. Rio de Janeiro: Serviço Gráfico do IBGE, 1950. Parte XII, Tomo 1.

BRASIL. Sinopse estatística do estado da Bahia. Rio de Janeiro: Serviço Gráfico do IBGE, 1942. n. 4.

Brazil, Law 4,632 ofJanuary 6, 1923.

FILGUEIRA, Manuel Rodriguez (Org.). Álbum artístico, commercial e industrial do estado da Bahia. Salvador: Biblioteca Pública do Estado da Bahia,1930.

SANTOS, Milton. Zona do cacau: introdução ao estudo geográfico. Salvador: 
Artes Gráficas, 1955.

SILVA CAMPOS, João. Crônicas da Capitania de São Jorge dos Ilhéus. Ilhéus: Editus, 2006. p. 377.

Received in: 30/03/2018 - Aproved in: 22/09/2018 